\title{
Neonatal Intensive Care Unit on-site surgery for congenital dia- phragmatic hernia
}

\author{
Alina Elena Gaiduchevici ${ }^{1}$, Cătălin Gabriel Cîrstoveanu ${ }^{1,5}$, Ana Mihaela Bizubac ${ }^{1}$, Carmen Mariana Herișeanu ${ }^{1}$, \\ Cristina Filip², Florin Dumitru Mihălțan, ${ }^{3,6}$, Radu-Iulian Spătaru' ${ }^{4,7}$
}

1 Neonatal Intensive Care Unit, “Maria S. Curie" Emergency Clinic Hospital for Children, Bucharest, Romania

2 Department of Cardiology, "Maria S. Curie" Emergency Clinic Hospital for Children, Bucharest, Romania

3 Department of Pneumology, "Marius Nasta" National Institute of Pneumology", Bucharest, Romania

4 Department of Pediatric Surgery, "Maria S. Curie" Emergency Clinical Hospital for Children, Bucharest, Romania

5 Discipline of Pediatrics, Faculty of Medicine, "Carol Davila" University of Medicine and Pharmacy, 020021 Bucharest, Romania

6 Discipline of Pneumology, Faculty of Medicine, "Carol Davila" University of Medicine and Pharmacy, 020021 Bucharest, Romania

7 Discipline of Pediatric Surgery, Faculty of Medicine, "Carol Davila" University of Medicine and Pharmacy, 020021 Bucharest, Romania

* Correspondence: Catalin Cîrstoveanu MD, PhD, "Carol Davila" University of Medicine and Pharmacy, Bucharest; Neonatal Intensive Care Unit, Emergency Clinical Hospital for Children "M.S. Curie", Bucharest, C. Brâncoveanu Avenue No.20, Zip Code 041451; email: catalin.cirstoveanu@umfcd.ro

\begin{abstract}
:
Background: This study presents the experience gained in the Newborn Intensive Care Unit (NICU) at "M. S. Curie" Emergency Hospital for Children in Bucharest after performing a series of bedside surgery interventions on newborns with congenital diaphragmatic hernia (CDH). We evaluate the advantages, complications, immediate and long-term outcome as well as morbidity.
\end{abstract}

Methods: We conducted a retrospective analysis of the data for all patients operated on-site between 2011 and 2020, in terms of pre- and post-operative stability, procedures performed, complications and outcomes.

Results: Our study is based on data from ten newborns cases, term or small for gestation age with birthweights ranging from 2300 to 3300 grams, operated on average, on the fifth day of life. The main reasons for operating on-site were the hemodynamical instability, the need to administer inhaled Nitic Oxide (iNO) and HFOV ventilation. There were no unforeseen events during surgery, no immediate postoperative complications and no surgery related mortality. A notices drawback was that the surgery team was not familiar with the new operating environment.

Conclusions: Our experience indicates that bedside surgery improves the likelihood of survival for critically ill neonates suffering from $\mathrm{CDH}$. No immediate complications could be associated with this practice.

Keywords: congenital diaphragmatic hernia, severe pulmonary hypertension, bedside surgery, NICU infrastructure

\section{Introduction}

The Newborn Intensive Care Unit at “M. S. Curie” Emergency Clinical Hospital for Children is one of the largest units of this type in the Eastern Europe. Built in 2013, 
inspired by Iowa Neonatal Intensive Care Unit, the NICU provides specialized intensive care treatment for surgical neonatal patients. There are 27 beds in individual rooms with areas of approx. 12 square meters. Each room is equipped with central air flow system (6 air change cycles per hour), 14 Hepa filters, 5 types of light (natural light, 2 projectors for procedures on the ceiling, and 1 indirect light), pendants with outlets for $\mathrm{O}_{2}$, medical air, vacuum, iNO, $\mathrm{CO}_{2}$, Helium, 22 electrical outlets, and areas for hand washing and disinfection. In addition, every room is equipped with one open incubator, one ventilator, one docking station with 10 to 15 infusion pumps, one transcutaneous monitor/Radiometer (10 beds), central monitoring Phillips Intellivue, Digistat/Ascom alarming equipment software, electronical data sheet for the patients/ICCA, individual medical cart for medication and consumables with extendable table for procedures.

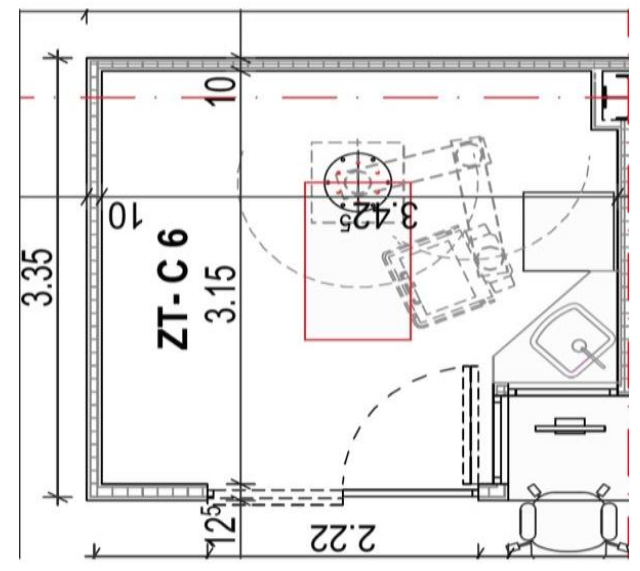

Image 1: Individual room plan

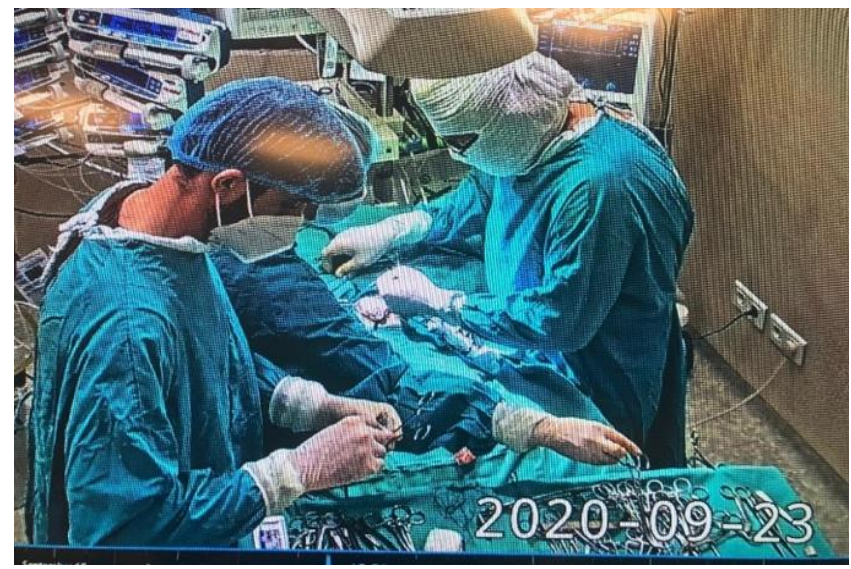

Image 2: Surgery onsite NICU

The "M.S. Curie" hospital provides medical care to children of all ages but it has no delivery room. As such, all patients admitted to the NICU are transferred from another hospital either by neonatal ambulance transport or helicopter. There are indications that the stress endured during the transport worsens the medical condition of the patients at the admission time. Transferring unstable neonates over long distances is frequently associated with significant deterioration of the general condition. Similar risks, albeit with lower incidence and severity, can occur during the patient's transfer from the NICU to the operating room (OP) [1]. Performing the intervention in the NICU can thus avoid the complications associated to discontinuation of monitoring, dislocation of artificial airways, accidental removal of vascular access, hypothermia, variations in heart rate and blood pressure [2, 3]. An increasing number of clinics around the world are applying this method and it can therefore be considered as a lifesaver practice for unstable patients that cannot be transported to the operating room $[4,5,6,7]$. The bedside surgery is a wellestablished practice at M.S. Curie NICU as both the technical equipment and medical expertise allow this type of intervention. Since 2011, a series of onsite interventions have been performed, including: surgery for retinopathy (laser therapy and Avastin injections), ligation of the patent ductus arteriosus, emergency atrial septostomy, placement of the Extracorporeal Membrane Oxygenation (ECMO) or Continuous Renal Replacement Therapy (CRRT) hemodialysis catheter, external ventricular drainage for hydrocephalus, tracheostomy, pleural drainage, peritoneal dialysis catheter placement and procedure. This study focuses on $\mathrm{CDH}$ cases as this is one of the most complicated conditions that could be operated in on-site.

\section{Materials and Methods}

This study is based on the retrospective analysis of ten patients with $\mathrm{CDH}$ that have been operated on-site in NICU between January 2011 and December 2020. The study was approved by the Ethics Committees of the "M. S. Curie" Emergency Hospital for children and "Carol Davila" University of Medicine and Pharmacy - Ref. Number 6/15/11/2020. In 
every case the decision to operate on-site was made following a multidisciplinary discussion involving medical doctors from neonatology, cardiology, anesthesiology and the surgery team, with the outcome documented in a medical report. The criteria to operate onsite, as well as the decision regarding proper surgery time, was a team decision based on: clinical and hemodynamical stability of each patient, dependency of the inotropic medication, HFOV, iNO and ECMO procedures. The arguments supporting this type of intervention have been presented to the parents and in all cases the decision to operate has been supported by the parent's consent (exception one emergency operation for pneumoperitoneum).

Upon admission into the NICU, a series of investigations are performed according to the internal evaluation protocol for $\mathrm{CDH}$. These investigations include microbiology studies (microbial skin culture, blood culture), complete blood count, kidney function, coagulation screening and inflammatory tests, genetic tests, serial blood gas tests. In addition, echocardiography is performed to exclude associated malformations, measure the rightto-left shunt, estimate the severity of pulmonary hypertension and evaluate the anatomy and velocities at the pulmonary veins and pulmonary arterial branches. The protocol also includes brain and kidney ultrasound and chest X-ray to evaluate the mediastinal shifting, pneumothorax, severity of atelectasis and presence of fluid at the side of the herniation. In the last years, since it has become possible to have patients on ECMO, the levels of Btype natriuretic peptide (BNP) are used as a prognostic marker for development of pulmonary hypertension as well as the need for ECMO [8-11]. In addition, a series of personal general data was collected and analyzed (e.g. antenatal diagnosis, gender, gestational age, type of birth, Apgar score) as well as details of the care procedure immediately after delivery (e.g. intubation, type of ventilation and $\mathrm{SpO}_{2}$ with minimal $\mathrm{FiO}_{2}$ on the first day of life). Since all newborns were transferred to our clinic mainly on the first day of life, this general data has been collected in the hospitals where the children were born.

Vital parameters of the patients have been recorded immediately prior and after the intervention. These metrics include: the values of the heart rate (HR), continuous measured by electrocardiography, the blood pressure (BP) either intermittently measured peripheral or via central preductal arterial line), preductal Oxygen Saturation (SpO2), blood gas (capillary or arterial stemple), glycemia, urine output, ventilation parameters, iNO and the doses of the continuous intravenous medication. In addition, the patients age at the day of the surgery, ASA anesthesiology risk, intraoperative events and modifications, the length of the intervention and surgery particularities (herniated organs, need for patch suture), immediate complication, long term complication and mortality have also been recorded.

In terms of organization for the surgery time, there were no major changes in patients care - medication was left in place, ventilation was mainly maintained in HFOV mode, the radiant warmer was switched to matrass manual mode and the temperature was monitored via a transcutaneous sensor. Although the risk of hypothermia was reduced by not transporting the patient to the OR it was considered necessary to evaluate the changes in temperature during the surgery time. As it is known, the general anesthesia inhibits thermoregulation, and this effect is added to the fact that newborns (especially premature) have less brown fat and the skin surface exposed during surgery is proportionally larger relative to older children [12].

Our surgeons can perform this type of surgery with minimally invasive methods (laparoscopy, thoracoscopy), but it was considered that these instable patients could not tolerate $\mathrm{CO}_{2}$ insufflation, so they were all operated via an open abdominal or thoracic approach [13]. The anesthesiology team used total intravenous anesthesia, mainly with Midazolam $(0,05-0,1 \mathrm{mg} / \mathrm{kg} / \mathrm{h})$ and Fentanyl $(2-10 \mu \mathrm{g} / \mathrm{kg} / \mathrm{h})$, muscle relaxation was provided during the surgery time using Atracrium or Vecuronium. Pre and post-surgery sedation was maintained by intermittent or continuous doses of narcotics and benzodiazepines.

The literature regarding on-site neonatal surgery is limited. While our dataset is affected by the same shortcomings as the other studies (e.g. small sample size), our sample 
is homogenous in terms of weight, gestational age and sex distribution which further supports the relevance of the results.

The data was summarized and analyzed using Excel as part of the Microsoft Office 365 Suite and the results were presented as mean / standard deviation and percentage.

\section{Results}

The study covers a period of 10 years and is based on data from 10 newborn patients with CDH operated on-site in the NICU. This represents 12,8 precent of the total of 78 $\mathrm{CDH}$ patients operated in our clinic during the observation period.

In our group both genders are equally represented, chronologically term newborns, one small and nine appropriate for gestational age (median birth weight 2,691g; range $2,300-3,300$ ). The type of birth was cesarian section in 8 cases and spontaneous vaginal birth for 2 cases, Apgar scores ranged between 3 and 8 . Six newborns were diagnosed antenatal with $\mathrm{CDH}$ (at a main gestational age of $26,5 \mathrm{WG}$ ) and 4 of them were uninvestigated pregnancies, and for this reason the normal protocol of intubating immediately after birth was not applied. Two patients have been reanimated via positive pressure ventilation (PPV) and intubated in the delivery room for respiratory distress and two of them were intubated after few hours when the general status deteriorated. Table 1 presents the summary statistics of the sample of patients included in this study.

Table 1. Summary statistics of population included in this study

\begin{tabular}{cc}
\hline Statistic & Results \\
\hline Number of cases included in study & 10 \\
Antenatal diagnostic of CDH & $6 / 10$ \\
Gestational age at birth (weeks) & $37-39$ (M: 37,6) \\
Birth weight (g) & $2300-3200(\mathrm{M}: 2,691)$ \\
Apgar score & $3-8$ (M: 5,8$)$ \\
Intubatedd as protocol & $6 / 10$ \\
HFOV on first day of life & $100 \%$ \\
iNO on first day of life & $60 \%$ \\
Inotropes on first day of life & $60 \%$ \\
\hline
\end{tabular}

Despite receiving adequate treatment for their condition, all patients were hemodynamically unstable at the time of surgery and received inotropic and vasopressors in association of one, two or three drugs. As such, half of the patients received Adrenaline (main dose $0,08 \mathrm{mcg} / \mathrm{kg} / \mathrm{min}$ ), $60 \%$ received Noradrenaline (main dose $0,8 \mathrm{mcg} / \mathrm{kg} / \mathrm{min}$ ), $60 \%$ received Milrinone (main dose $0,5 \mathrm{mcg} / \mathrm{kg} / \mathrm{min}$ ), 70\% received Dopamine (mean dose 15 $\mathrm{mcg} / \mathrm{kg} / \mathrm{min}$ ) and $60 \%$ were administered Dobutamine (mean dose $12 \mathrm{mcg} / \mathrm{kg} / \mathrm{min}$ ). Table 2 presents the simultaneously administered inotropic medication.

Table 2. Simultaneously administered inotropic medication

\begin{tabular}{ccccccccccc}
\hline Patient & $\mathbf{1}$ & $\mathbf{2}$ & $\mathbf{3}$ & $\mathbf{4}$ & $\mathbf{5}$ & $\mathbf{6}$ & $\mathbf{7}$ & $\mathbf{8}$ & $\mathbf{9}$ & $\mathbf{1 0}$ \\
\hline Dopamine & $\mathrm{X}$ & $\mathrm{X}$ & $\mathrm{X}$ & $\mathrm{X}$ & & $\mathrm{X}$ & $\mathrm{X}$ & $\mathrm{X}$ & & $\mathrm{X}$ \\
Dobutamine & $\mathrm{X}$ & $\mathrm{X}$ & & $\mathrm{X}$ & $\mathrm{X}$ & $\mathrm{X}$ & & & $\mathrm{X}$ & $\mathrm{X}$ \\
Adrenaline & & $\mathrm{X}$ & $\mathrm{X}$ & & $\mathrm{X}$ & $\mathrm{X}$ & $\mathrm{X}$ & & & \\
Noradrenaline & $\mathrm{X}$ & $\mathrm{X}$ & & & & $\mathrm{X}$ & $\mathrm{X}$ & $\mathrm{X}$ & & \\
Milrinone & $\mathrm{X}$ & & & & & $\mathrm{X}$ & $\mathrm{X}$ & $\mathrm{X}$ & & $\mathrm{X}$ \\
\hline
\end{tabular}

All patients were on HFOV ventilation before surgery and needed continuous iNO (mean dose was $20 \mathrm{ppm}$ ). One patient was on ECMO for 4 days prior to surgery, out of ECMO and operated few hours later when the coagulation was on normal limits. After 
surgery, the patient was back on ECMO for another 3 days. Another patient was operated in emergency for pneumothorax and pneumoperitoneum and for yet another patient the surgery took place in special safety conditions as needed when involved in the care of a newborn to a human immunodeficiency virus (HIV) positive mother.

As suggested in the literature, there is no ideal time for repairing CDH [14, 15]. In our study the average age at date of the surgery was approx. 5,7 days (range from 2 to 10 days). The one case operated on the second day of life (28 hours of life) was a surgery emergency for pneumothorax and pneumomediastinum, and the one operated on the 10 th day of life was due to the prolonged unstable status.

All underwent laparotomy, the operative time ranged from 65 to 140 minutes (mean 94,5 minutes). There was no difference in the duration of the surgery compared to a usual surgery performed in the OR taking into consideration the severity of the cases. In 7 cases, diaphragmatic defect was on the left side and on the right side for the remaining 3 patients. The survivors were 3 left side $\mathrm{CDH}$ and 1 right side $\mathrm{CDH}$ newborns confirming the previous findings in the literature that mortality is higher when $\mathrm{CDH}$ is on the right side [16]. Regarding the type of the surgery, primary repair was possible for 8 patients while the other 2 needed synthetical patch repair due to diaphragm agenesia. Both of them associated severe lung hypoplasia and did not survive.

In term of the anatomy of the $\mathrm{CDH}$, all our cases had small intestine in the thorax. All left side $\mathrm{CDH}$ cases had herniated stomach and $85 \%$ had herniated large intestine and spleen.

The liver was herniated in the thorax for 8 out of 10 cases. The other 2 cases (one left and one right side hernias) were also the ones with good outcome, as the literature is also suggesting positive prognostic for not herniated liver [17, 18].

Regarding the associated pathology, 8 patients had congenital cardiac anomalies, 3 patients had hypoxic-ischemic encephalopathy and 1 patient was an infant exposed to HIV mother. All the patients had persistent pulmonary hypertension and 9 of them associated cardiac failure.

In terms of non-surgery related complications, 1 patient with severe pulmonary hemorrhage, 2 patients with sepsis and 1 patient with chylothorax did not survive while another patient with chylothorax and 1 patient with right jugular thrombosis and hydropericardium corelated to ECMO had good outcomes (Table 3).

Table 3. General characteristics of patient population including associated pathology, complications and outcomes

\begin{tabular}{|c|c|c|c|c|c|c|c|}
\hline Case & $\begin{array}{c}\text { Age } \\
\text { when } \\
\text { operated } \\
\text { (days) }\end{array}$ & $\begin{array}{c}\text { Side of the } \\
\text { diaphragmatic } \\
\text { defect }\end{array}$ & $\begin{array}{c}\text { Herniated } \\
\text { liver }\end{array}$ & $\begin{array}{l}\text { Surgery } \\
\text { duration } \\
\text { (min) }\end{array}$ & $\begin{array}{l}\text { Associated } \\
\text { pathologies/ } \\
\text { pre surgery } \\
\text { complications }\end{array}$ & Complications & Outcome \\
\hline 1 & 3 & left & yes & 100 & $\begin{array}{c}\text { Mild left } \\
\text { ventricle } \\
\text { hypoplasia } \\
\text { ASD } \\
\text { Congestive } \\
\text { heart failure }\end{array}$ & $\begin{array}{c}\text { Persistent } \\
\text { pulmonary } \\
\text { hypertension } \\
\text { Cardiac failure }\end{array}$ & Negative \\
\hline 2 & 4 & left & yes & 80 & $\begin{array}{c}\text { Mitral } \\
\text { regurgitation } \\
\text { Congestive } \\
\text { heart failure }\end{array}$ & $\begin{array}{c}\text { Persistent } \\
\text { pulmonary } \\
\text { hypertension } \\
\text { Cardiac failure }\end{array}$ & Negative \\
\hline 3 & 3 & right & yes & 120 & ASD & $\begin{array}{c}\text { Persistent } \\
\text { pulmonary } \\
\text { hypertension }\end{array}$ & Negative \\
\hline
\end{tabular}




\begin{tabular}{|c|c|c|c|c|c|c|c|}
\hline & & & & & & $\begin{array}{l}\text { Cardiac failure } \\
\text { Pulmonary } \\
\text { hemorrhage }\end{array}$ & \\
\hline 4 & 10 & left & yes & 90 & $\begin{array}{c}\text { Hypoxic- } \\
\text { ischemic } \\
\text { encephalopathy }\end{array}$ & $\begin{array}{c}\text { Persistent } \\
\text { pulmonary } \\
\text { hypertension } \\
\text { Cardiac failure } \\
\text { Chylothorax }\end{array}$ & Negative \\
\hline 5 & 7 & left & yes & 100 & $\begin{array}{l}\text { Mild hypoxic - } \\
\text { ischemic } \\
\text { encephalopathy }\end{array}$ & $\begin{array}{c}\text { Persistent } \\
\text { pulmonary } \\
\text { hypertension } \\
\text { Cardiac failure } \\
\text { Sepsis }\end{array}$ & Negative \\
\hline 6 & 3 & right & yes & 110 & $\begin{array}{c}\text { Right } \\
\text { pulmonary vein } \\
\text { hypoplasia }\end{array}$ & $\begin{array}{c}\text { Persistent } \\
\text { pulmonary } \\
\text { hypertension } \\
\text { Cardiac failure } \\
\text { Sepsis }\end{array}$ & Negative \\
\hline 7 & 7 & left & no & 140 & $\begin{array}{c}\text { ASD } \\
\text { Congestive } \\
\text { heart failure - } \\
\text { ECMO }\end{array}$ & $\begin{array}{c}\text { Persistent } \\
\text { pulmonary } \\
\text { hypertension } \\
\text { Cardiac failure } \\
\text { Right jugular } \\
\text { thrombosis } \\
\text { Hydropericardiu } \\
\text { m }\end{array}$ & Positive \\
\hline 8 & 10 & left & no & 70 & $\begin{array}{c}\text { Hypoxic - } \\
\text { ischemic } \\
\text { encephalopathy } \\
\text { HIV exposed }\end{array}$ & $\begin{array}{c}\text { Persistent } \\
\text { pulmonary } \\
\text { hypertension } \\
\text { Cardiac failure } \\
\text { Chylothorax }\end{array}$ & Positive \\
\hline 9 & 2 & right & yes & 65 & $\begin{array}{c}\text { Preoperatory } \\
\text { pneumothorax } \\
\text { and } \\
\text { pneumoperitone } \\
\text { um }\end{array}$ & $\begin{array}{c}\text { Persistent } \\
\text { pulmonary } \\
\text { hypertension } \\
\text { Cardiac failure } \\
\text { Inferior vena cava } \\
\text { thrombosis }\end{array}$ & Positive \\
\hline 10 & 8 & left & yes & 70 & ASD & $\begin{array}{c}\text { Persistent } \\
\text { pulmonary } \\
\text { hypertension }\end{array}$ & Positive \\
\hline
\end{tabular}

During surgery the ventilator settings were maintained with constant maximal parameters for each patient in order to maintain preductal $\mathrm{pO}_{2}$ above $85 \%$. $\mathrm{FiO}_{2}$ ranged 

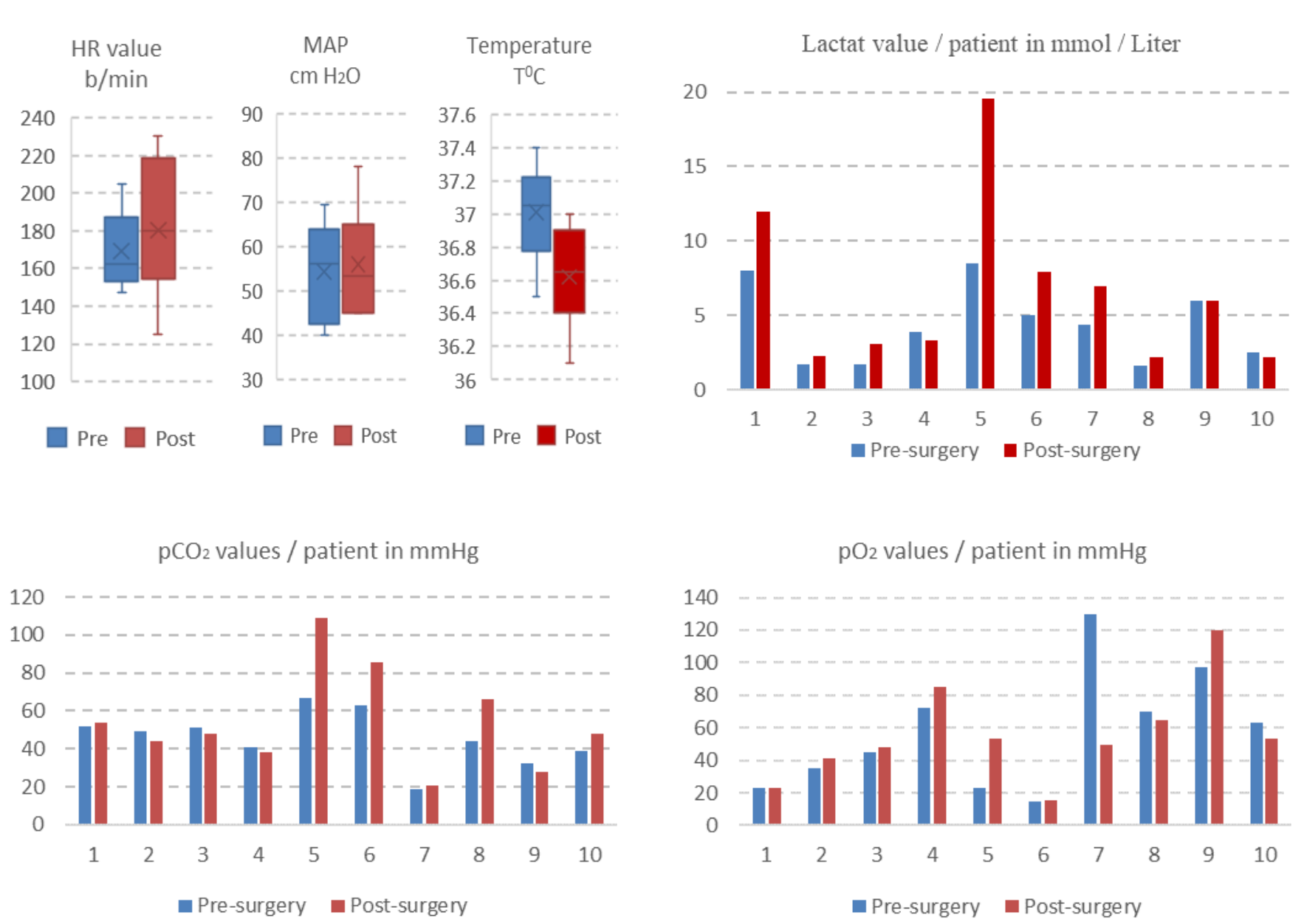

from 65 to $100 \%$ (mean 95,5\%) and mean airway pressure ranged from 6 to $20 \mathrm{~cm} \mathrm{H}_{2} \mathrm{O}$ (mean value $12,5 \mathrm{~cm} \mathrm{H}_{2} \mathrm{O}$ ).

Regarding blood gas analyses, the $\mathrm{pH}$ value ranged from 7.17 to 7.5 (mean value 7,33), 7 patients had post operatory a higher level of lactate, 1 had constant value and 2 had minimal decreased level value. Corelated to the $\mathrm{pH}$ level, 6 patients had a mild to severe increased $\mathrm{pCO}_{2}$ levels and 4 had a mild $\mathrm{pCO}_{2}$ improvement. When the $\mathrm{SpO}_{2}$ was analyzed, before and immediately after the surgery, 5 patients had an improved level, 2 had a constant level and 2 had a mild decreasing tendency. Since the precision of the capillary samples is insufficient when compared to arterial samples the gas analyses were conducted in terms of relative improvement or deterioration and not necessarily in absolute value, in line with similar practices report in the literature [19]. A direct correlation between the gas analyses and the final outcome was not established except for the 2 patients with the highest lactate level who died days after the surgery (Figure 1).

The body temperature was maintained within the normal range for for all the patients. The mean HR increased from 169,1 beats/min to 180,3 beats/min.

During the study time, the ECMO procedure was not routinely applied. However, the only patient under ECMO included in this study is the first patient in our clinic who was on ECMO (veno-venous initially, then veno-arterial due to unstable right ventricle) and operated with a good outcome.

Historically, the ECMO procedure could be provided in our clinic since 2016, and for the first 2 patients who were on veno-venous ECMO, the surgery was not possible due to severe, unstable hemodynamic status. For this reason, the majority of patients with severe $\mathrm{CDH}$ underwent surgical repair despite the ECMO criteria being met.

The overall mortality rate was $60 \%$ due to the severity of the cases. However, note of the negative outcomes was determined by perioperative event. 
Figure 1. Top Left - Heart rate, mean arterially pressure, Skin temperature value measured pre and post-surgery, Top right - Lactate value measured pre and post-surgery, Bottom Left $-\mathrm{pCO}_{2}$ value measured pre and post-surgery, Bottom right $-\mathrm{pO}_{2}$ value measured pre and post-surgery

\title{
4. Conclusions
}

Our experience indicates that bedside surgery increases the chances of survival for the very severe cases non- transferable to OP.

Neonatal surgery in NICU is a safe procedure that can be utilized in cases of neonates with severe respiratory failure, severe pulmonary hypertension and hemodynamically unstable. As such, it is recommended for ICU planners to consider creating the infrastructure needed to conduct on-site surgery in NICU.

\begin{abstract}
Author Contributions: Conceptualization, A.E.G, C.G.C. A.M.B, C.M.H. and C.F.; methodology, A.E.G.; software, A.E.G.; validation, C.G.C., F.D.M. and R-I.S.; formal analysis, A.E.G.; resources, C.G.C.; data curation, A.E.G.; writing-original draft preparation, A.E.G.; writing-review and editing, C.G.C.; supervision, C.G.C. and F.D.M.; project administration, A.E.G.; All authors have read and agreed to the published version of the manuscript.
\end{abstract}

Funding: This research received no external funding

Informed Consent Statement: Written informed consent has been obtained from the patients to in order to use their data for academical purposes.

Conflicts of Interest: The authors declare that they have no financial or nonfinancial conflicts of interest related to the subject matter or materials discussed in the manuscript.

\section{References}

1. Mallick MS, Jado AM, Al-Bassam AR. Surgical procedures performed in the neonatal intensive care unit on critically ill neonates: feasibility and safety. Ann Saudi Med. 2008 Mar-Apr;28(2):105-8. doi: 10.5144/0256-4947.2008.105. PMID: 18398286; PMCID: PMC6074523.

2. Fanning NF, Casey W, Corbally MT. In-situ emergency paediatric surgery in the intensive care unit. Pediatr Surg Int. 1998 Oct;13(8):587-9. doi: 10.1007/s003830050410. PMID: 9799382.

3. Beckmann U, Gillies DM, Berenholtz SM, Wu AW, Pronovost P. Incidents relating to the intra-hospital transfer of critically ill patients. An analysis of the reports submitted to the Australian Incident Monitoring Study in Intensive Care. Intensive Care Med. 2004 Aug;30(8):1579-85. doi: 10.1007/s00134-004-2177-9. Epub 2004 Feb 26. PMID: 14991102.

4. Hall NJ, Stanton MP, Kitteringham LJ, Wheeler RA, Griffiths DM, Drewett M, Burge DM. Scope and feasibility of operating on the neonatal intensive care unit: 312 cases in 10 years. Pediatr Surg Int. 2012 Oct;28(10):1001-5. doi: 10.1007/s00383-012-3161-z. Epub 2012 Aug 21. PMID: 22907723.

5. Pelizzo G, Bagolan P, Morini F, Aceti M, Alberti D, Andermarcher M, Avolio L, Bartoli F, Briganti V, Cacciaguerra S, Camoglio FS, Ceccarelli P, Cheli M, Chiarenza F, Ciardini E, Cimador M, Clemente E, Cozzi DA, Dall' Oglio L, De Luca U, Del Rossi C, Esposito C, Falchetti D, Federici S, Gamba P, Gentilino V, Mattioli G, Martino A, Messina M, Noccioli B, Inserra A, Lelli Chiesa P, Leva E, Licciardi F, Midrio P, Nobili M, Papparella A, Paradies G, Piazza G, Pini Prato A, Rossi F, Riccipetitoni G, Romeo C, Salerno D, Settimi A, Schleef J, Milazzo M, Calcaterra V, Lima M. Bedside surgery in the newborn infants: survey of the Italian society of pediatric surgery. Ital J Pediatr. 2020 Sep 16;46(1):134. doi: 10.1186/s13052-020-00889-2. PMID: 32938472; PMCID: PMC7493058.

6. Kumar Sinha S, Neogi S. Bedside neonatal intensive care unit surgery- myth or reality! J Neonatal Surg. 2013 Apr 1;2(2):20. PMID: 26023440; PMCID: PMC4420370.

7. Wang YL, Jeng SF, Tsao PN, Chou HC, Chen CY, Hsieh WS. Operating Room Within the Neonatal Intensive Care Unit--Experience of a Medical Center in Taiwan. Pediatr Neonatol. 2015 Aug;56(4):220-5. doi: 10.1016/j.pedneo.2014.10.003. Epub 2014 Nov 13. PMID: 25500106.

8. Snoek KG, Reiss IK, Greenough A, Capolupo I, Urlesberger B, Wessel L, Storme L, Deprest J, Schaible T, van Heijst A, Tibboel D; CDH EURO Consortium. Standardized Postnatal Management of Infants with Congenital Diaphragmatic Hernia in Europe: The CDH EURO Consortium Consensus - 2015 Update. Neonatology. 2016;110(1):66-74. doi: 10.1159/000444210. Epub 2016 Apr 15. PMID: 27077664.

9. Partridge EA, Hanna BD, Rintoul NE, Herkert L, Flake AW, Adzick NS, et al and Partrige, Brain-type natriuretic peptide levels correlate with pulmonary hypertension and requirement for extracorporeal membrane oxygenation in congenital diaphragmatic hernia. s.1. : Journal of Pediatric Surgery, 2015, Vols. 50(2):p. 263-266. Doi: 10.1016/j.jpedsurg.2014.11.009 
10. Steurer MA, Moon-Grady AJ, Fineman JR, et al. B-type natriuretic peptide: prognostic marker in congenital diaphragmatic hernia. Pediatric Research. 2014 Dec;76(6):549-554. DOI: 10.1038/pr.2014.136.

11. Heindel K, Holdenrieder S, Patel N, Bartmann P, Schroeder L, Berg C, Merz WM, Mueller A, Kipfmueller F. Early postnatal changes of circulating N-terminal-pro-B-type natriuretic peptide in neonates with congenital diaphragmatic hernia. Early Hum Dev. 2020 Jul;146:105049. doi: 10.1016/j.earlhumdev.2020.105049. Epub 2020 Apr 25. PMID: 32402829.

12. Boyer TJ, Kritzmire SM. Neonatal Anesthesia. 2021 Feb 4. In: StatPearls [Internet]. Treasure Island (FL): StatPearls Publishing; 2021 Jan-. PMID: 31082074.

13. Yang EY, Allmendinger N, Johnson SM, Chen C, Wilson JM, Fishman SJ. Neonatal thoracoscopic repair of congenital diaphragmatic hernia: selection criteria for successful outcome. J Pediatr Surg. 2005 Sep;40(9):1369-75. doi: 10.1016/j.jpedsurg.2005.05.036. PMID: 16150335.

14. Nicola Lewis, MBBS, FRCS, FRCS (Paed Surg) and Chief Editor: Eugene S Kim, MD, FACS, FAAP. Diaphragmatic Hernias. https://emedicine.medscape.com/article/934824-overview, Updated: Oct 22, 2019.

15. Okuyama H, Usui N, Hayakawa M, Taguchi T; Japanese CDH study group. Appropriate timing of surgery for neonates with congenital diaphragmatic hernia: early or delayed repair? Pediatr Surg Int. 2017 Feb;33(2):133-138. doi: 10.1007/s00383-016-40031. Epub 2016 Nov 7. PMID: 27822779.

16. Duess JW, Zani-Ruttenstock EM, Garriboli M, Puri P, Pierro A, Hoellwarth ME. Outcome of right-sided diaphragmatic hernia repair: a multicentre study. Pediatr Surg Int. 2015 May;31(5):465-71. doi: 10.1007/s00383-015-3695-y. Epub 2015 Mar 24. PMID: 25801417.

17. Le LD, Keswani SG, Biesiada J, Lim FY, Kingma PS, Haberman BE, Frischer J, Habli M, Crombleholme TM. The congenital diaphragmatic hernia composite prognostic index correlates with survival in left-sided congenital diaphragmatic hernia. J Pediatr Surg. 2012 Jan;47(1):57-62. doi: 10.1016/j.jpedsurg.2011.10.020. PMID: 22244393; PMCID: PMC3870853.

18. Mullassery D, Ba'ath ME, Jesudason EC, Losty PD. Value of liver herniation in prediction of outcome in fetal congenital diaphragmatic hernia: a systematic review and meta-analysis. Ultrasound Obstet Gynecol. 2010 May;35(5):609-14. doi: 10.1002/uog.7586. PMID: 20178116.

19. Collot V, Malinverni S, Schweitzer E, Haltout J, Mols P, Bartiaux M. Agreement between arterial and capillary pH, pCO2 and lactate in patients in the emergency department. medRxiv 2020.06.11.20128223; doi:https://doi.org/10.1101/2020.06.11.20128223 